\title{
Synthesis of Salicylate and Salicylamide Alcohols for the Preparation of Phosphorodiamidates and Ifosfamide Prodrugs
}

\author{
ASHUTOSH PAL \\ Department of Chemistry, Raja Peary Mohan College, West Bengal, India. \\ ${ }^{*}$ Corresponding author E-mail: ashupal33@gmail.com
}

http://dx.doi.org/10.13005/ojc/370205

(Received: January 12, 2021; Accepted: March 22, 2021)

\begin{abstract}
Prodrugs are derivatives of drugs which gives parent drug or release drug when it breaks inside the body by the presence of suitable enzyme, and then exert desired pharmacological effect. For many years, prodrug strategy has been developed enormously to solve many unwanted drug properties. In drug discovery and development, prodrugs have well-known pharmacokinetic effects of pharmacologically nimble products. Almost $10 \%$ of drugs permitted whole world are classified as prodrugs, where the application of a prodrug method during initial stages of development is an emergent fashion. Phosphorodiamidates prodrugs are well known anticancer agents particularly against leucomia. To improve the selectivity of the chemotherapeutic agents and reduce systemic toxicity, I herein report different types of salicylate and salicylamide alcohols for the preparation of phosphorodiamidates and ifosfamide prodrugs.
\end{abstract}

Keywords: Prodrugs, Drugs, Suitable enzyme, Phosphorodiamidates, Ifosfamide prodrugs, Salicylate, Salicylamide alcohols.

\section{INTRODUCTION}

Prodrugs are precursors of drug substances which are pharmacologically inactive it necessary either enzymatic alteration or chemically transformation to the main drug in vivo so order as to achieve a pharmacological consequence. Prodrug is more potent than parent drug just like nascent hydrogen. Sometimes parent drug molecule becomes less delivery properties than its prodrug molecule ${ }^{1}$. The concept of prodrug is justified due to it allow the proper functioning drug to surpass better of barrier that would obstruct it from reaching the site of action to exercise the necessary pharmacological activity.
At present due to unwanted side effects of maximum drugs like poor bioavailability, incomplete absorption, short period of action, non-specificity, organoleptic properties, less solubility in water, high first-pass metabolism or other adversarial effects (propranolol); short half-life arise due to metabolic instability, bad permeability or absorption (ampicillin); (dopamine); site specificity is not properly (anticancer agents); unfriendly organoleptic properties (chloramphenicol); incomplete absorption (epinephrine); cause difficult during formulation and disadvantageous effects and toxicity ${ }^{2-4}$ that hamper their therapeutic effectiveness.

This is an Open Access article licensed under a Creative Commons license: Attribution 4.0 International (CC- BY). Published by Oriental Scientific Publishing Company @ 2018 
In the maneuver of drug delivery process the prodrug approach is quickly taking a crucial part during treatment of patient. The implementation of prodrug strategy in the past 30 years has accelerated a firm progress in the biopharmaceutical, physicochemical and/or pharmacokinetic attributes of the pharmacologically active substances. It is measured the success of the prodrug approach from the survey that the number of prodrugs are presently on the market. About 10 to $15 \%$ of promoted drugs can be categorized as prodrugs now and up to year 2008 , $30 \%$ of approved minor molecular weight drugs were prodrugs ${ }^{5-7}$. During the period of 2008$2017,12 \%$ of drugs molecules approved by the FDA were prodrugs ${ }^{8-10}$.

Though enormous advances have occurred in the field of cancer, it still remains a major health problem and it has been reported that cancer is the cause of death up to $25 \%$ in USA. At the present time, cyclophosphamide (CPA) is the most frequently used agent of the alkylating agent class in medical oncology ${ }^{11-17}$. Two congeners, ifosfamide (IPM) and trotosfamide are also in clinical cancer treatment. CPA has better therapeutics index (particularly in the treatment of ovarian and breast cancer) than other mustard drugs like nitrogen mustard and exhibit broad area of clinical efficacy though the main biotransformation pathway of phosphamide drug is well designed, its appliance of tumoridical selectivity remains controversial ${ }^{18-22}$.

This article presents two types alcohols on which first type approach is ester form so that the prodrug can cleave by the presence of esterase and release ifosphoramide mustard with physically healthy compound salicylic acid and the second type that is amide form should fail to cleave by the esterase enzyme because these are amide derivatives which should not cleaved and release drug by the presence of esterase.

\section{Chemistry}

The synthesis of the target alcohols was carried out as shown in Scheme. 2 to 4 and phosphorodiamidates can be easily synthesized by the reaction of alcohol and phosphorous oxychloride followed by the treatment of chloroethylamine hydrochloride as in Scheme $1^{15}$.

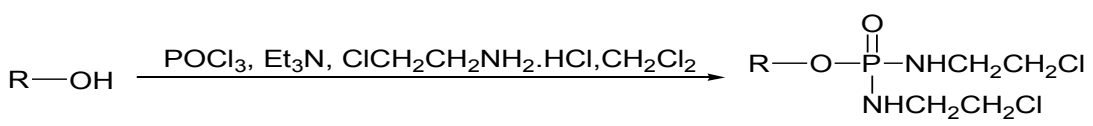

Scheme 1. Synthesis procedure of phosphorodiamidates

Compounds $4 a-b, 10$ and $14 a-b$ those have not been reported previously, were prepared by stirring with the mixture of phenyl salicylate and the corresponding aldehyde ${ }^{23}$ using DABCO as base in absence of solvent ${ }^{24}$ as shown in Scheme 2 .
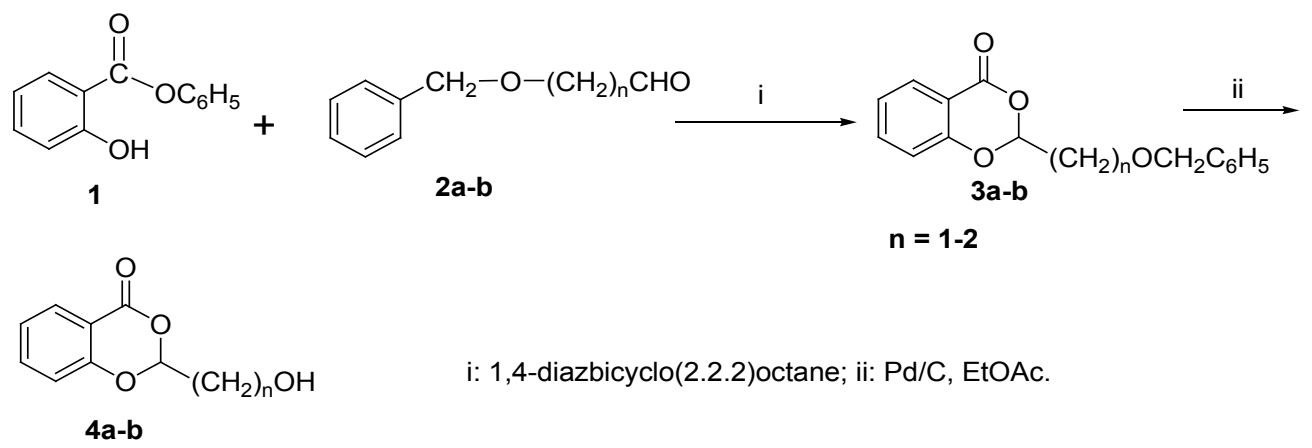

i: 1,4-diazbicyclo(2.2.2)octane; ii: Pd/C, EtOAc.

Scheme 2. Synthesis of salicylate alcohols

The synthetic approach to $\mathbf{1 0}$ is based on $\mathbf{6}$, and 7. But in that case aldehyde was nitro substituted and salicylate was 4-benzyloxy substituted (Scheme 3). Molecules 14a-b were generated from $\mathrm{N}$-methyl salicylamide and the corresponding alcohol in presence of ortho phosphoric acid in tetrahydofuran at refluxing temperature ${ }^{25}$ shown in Scheme 4. Hydrogenelysis of $\mathbf{3} \mathbf{a}-\mathbf{b}$ and $\mathbf{1 3} \mathbf{a}-\mathbf{b}$ were carried out over $10 \% \mathrm{Pd} / \mathrm{C}$ under pressure using ethyl acetate as solvent and the trace of $70 \%$ perchloric acid as catalyst yielded corresponding alcohols. Alcohol 10 was synthesized by photolysis ${ }^{26}$ from compound 9 . 


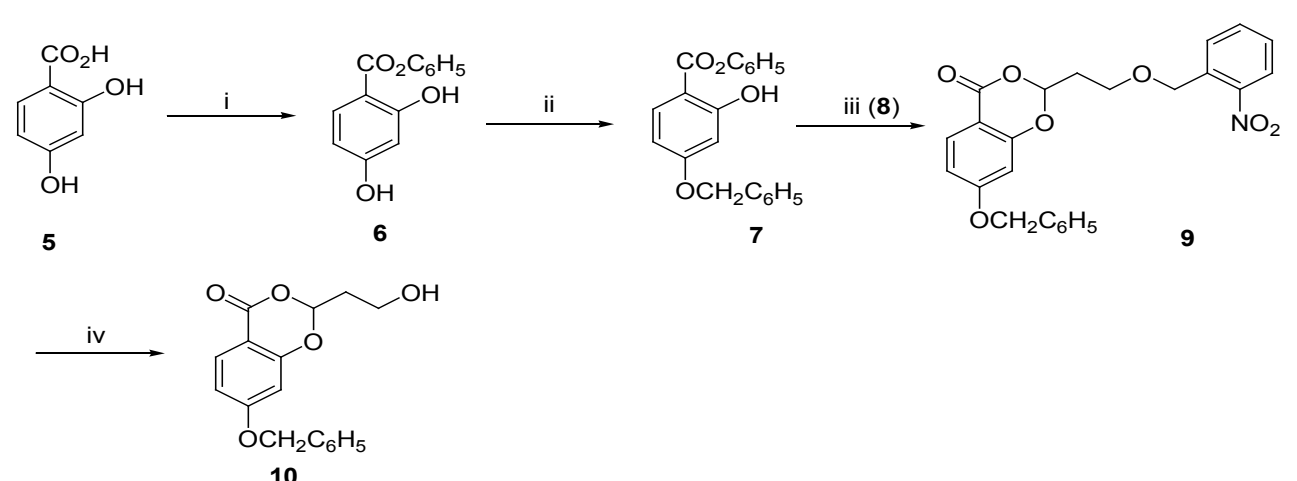

1: $\mathrm{PhOH},\left(\mathrm{CF}_{3} \mathrm{CO}\right)_{2} \mathrm{O}$; ii: $\mathrm{C}_{6} \mathrm{H}_{5} \mathrm{CH}_{2} \mathrm{Br},\left(\mathrm{CH}_{3}\right)_{2} \mathrm{CO}$; iii: $\left(2-\mathrm{NO}_{2}\right) \mathrm{C}_{6} \mathrm{H}_{4} \mathrm{CH}_{2} \mathrm{OCH}_{2} \mathrm{CH}_{2} \mathrm{CHO}$ (8), DABCO, iv: hn, THF Scheme 3. Synthesis of substituted salicylate alcohols<smiles>CNC(=O)c1ccccc1O</smiles><smiles>CCCCCCO</smiles>
$n=1-2$

i: $\mathrm{H}_{3} \mathrm{PO}_{4}$, THF; ii: $\mathrm{Pd} / \mathrm{C}$, EtOAc

Scheme 4. Synthesis of salicylamide alcohols

Cyclic acetal phosphorodiamidates derivatives were synthesized as the test reaction to confirm the formation of mustard using those alcohols. Alcohols 4a-b were converted into phosphorodichloridates by $\mathrm{POCl}_{3}$ and $\left(\mathrm{C}_{2} \mathrm{H}_{5}\right)_{3} \mathrm{~N}$ in dichloromethane at $-20^{\circ} \mathrm{C}$ which in situ, were converted to phosphorodiamidates by the treatment with 2-fold molar equivalent of 2-chloroethylamine hydrochloride Scheme 1.

\section{EXPERIMENTAL}

All NMR spectra were drawn from IBMBrucker Model NR/200 AF spectrometer in the FT model, in deutero chloroform where tetramethyl sillane used as an internal standard. The chemical shift represents $\delta \mathrm{ppm}$ and coupling constant represents $\mathrm{J}$ in hertz and using by Hoover capillary apparatus melting points of the compounds were checked. Reactions in this article were carried out in dry glass apparatus and inert atmosphere using nitrogen and helium as inert gas. Dry and analytical solvents were used for all reactions. The reaction progress and homogeneity of the reaction mixture were checked by TLC coated with silica gel that was run in glass plates using the following solvent mixtures (a), $\mathrm{CHCl}_{3} / \mathrm{MeOH}$ (19:1 to 9.5:0.5 v/v); (b), hexane/EtOAc (9:1 to $1: 1)$ and (c), $100 \%$ diethyl ether. TLC plates were visualized under a UV lamp $(254 \mathrm{~nm})$ and spraying agent used as anisaldehyde solution in $95 \%$ ethanol and heated to $100^{\circ} \mathrm{C}$ for 5 min appeared as different coloured spots. Pure products were obtained by chromatography with neutral alumina or on silica gel with the solvent mixture of hexane/EtOAc or $\mathrm{CH}_{2} \mathrm{Cl}_{2} / \mathrm{MeOH}$. The reactions mixture were extracted with diethyl ether, ethyl acetate, dichloromethane or trichloromethan and ranched with aqua, brine solution, saturated sodium bicarbonate whenever necessary and then dried with anhydrous $\mathrm{MgSO}_{4}$. Solutions were concentrated using rotary evaporator under reduced pressure and dried.

\section{3-Benzyloxypropionaldehyde (2a)}

In a mixture of phenyl methanol $(61.5 \mathrm{~mL}$, $64.25 \mathrm{~g}, 0.595 \mathrm{~mol}), 2$-chloroethanoic acid (3.36 g), and $\mathrm{NaOH}(1.425 \mathrm{~g})$ in $7.50 \mathrm{~mL}$ water added slowly with gentle shaking for $15 \mathrm{~min}$ to acroline $(50 \mathrm{~mL}$, 
$42.95 \mathrm{~g}, 0.75 \mathrm{~mol}$ ). At $40^{\circ} \mathrm{C} 15 \mathrm{~mL}$ aceteic acid drop wise added to the reaction system and maintained it at $40^{\circ} \mathrm{C}$ during 80 hours. The crude reaction mixture was worked up with EtOAc and acid was removed by wash with aqua $(75 \mathrm{~mL} \times 3)$ and passed through anhydrous $\mathrm{MgSO}_{4}$. After work up the organic solvent was dried and crude product made pure by vacuum distillation at $100^{\circ} \mathrm{C}(0.3 \mathrm{~mm} \mathrm{Hg})$ pressure followed by the removal of volatile starting materials and side products. The residue remained as viscous oil was aldehyde 2 a confirmed from NMR studies. The raw material was taken for subsequent steps and there is no necessary for purication. Crude yield was 33 g (32\%). Proton NMR values were determined by deuterium chloroform; Proton-NMR $\delta: 9.78(-\mathrm{CHO})$, $7.29(\mathrm{Ar}-\mathrm{H}), 4.52\left(\mathrm{C}_{6} \mathrm{H}_{5} \mathrm{CH}_{2}\right), 3.80\left(-\mathrm{O}-\mathrm{CH}_{2}\right), 2.68$ $\left(-\mathrm{CH}_{2}\right)$; C-13 NMR $\left(\mathrm{CDCl}_{3}\right) \delta: 200.87,137.70,127.50$ and 127.34 (aromatic), 72.92 (benzylic), 66.57, 43.58; MS $\left(\mathrm{C}_{9} \mathrm{H}_{10} \mathrm{O}_{2}\right)$ calcd. 150.068 found $\mathrm{MH}^{+}$151.1.

\section{2-(2'-Benzyloxyethyl)-4H-1,3-benzdioxin-4-one (3a)}

This reaction was performed with a mixture DABCO (1.1g, $10 \mathrm{mmol}),(2.15 \mathrm{~g})$ phenyl salicylate and $(1.518 \mathrm{~g})$ of 3-benzyloxypropionaldehyde without solvent and was warmed to $40^{\circ} \mathrm{C}$ during 12 min then it continued during overnight at normal warmth condition where suspension formed which was extracted by EtOAc and was washed thoroughly with $30 \mathrm{~mL} 2 \% \mathrm{NaOH}$ solution two times and aqua (30 $\mathrm{mL} \times 2$ ) and passed through drying agent. The crude compound was achieved after removal of organic solvent which made pure by chromatography (ca. 200 g) taking hexane/EtOAc $(98: 2, \mathrm{v} / \mathrm{v})$ as solvent mixture to yield 3a clear liquid form (880 mg, 68\%): $\mathrm{R}_{f} 0.55$ (95:5, hexane/EtOAc). Proton NMR $\delta: 7.98(\mathrm{Ar}-\mathrm{H})$, 7.55 (Ar-H), $7.30(\mathrm{Ar}-\mathrm{H})), 7.16(\mathrm{Ar}-\mathrm{H}), 7.00(\mathrm{Ar}-\mathrm{H}))$, 5.81 (-O-CH-O-), $4.52\left(\mathrm{C}_{6} \mathrm{H}_{5} \mathrm{CH}_{2}\right), 3.76\left(-\mathrm{O}-\mathrm{CH}_{2}-\mathrm{CH}_{2}-\right)$, $2.35\left(-\mathrm{O}-\mathrm{CH}_{2}-\mathrm{CH}_{2}-\right)$. Mass spectroscopy $\left(\mathrm{C}_{16} \mathrm{H}_{14} \mathrm{O}_{4}\right)$ calcd. 270.089 found $\mathrm{MH}^{+}$271.2.

\section{2-(2'-Hydroxyethyl)-4H-1,3-benzdioxin-4-one (4a)}

(1.0 g, $3.52 \mathrm{mmol}) 2-(2$ '-benzyloxyethyl)$4 \mathrm{H}-1$, 3-benzdioxin-4-one $3 \mathrm{a}$ in $10 \mathrm{~mL}$ ethyl acetate containing $10 \mu \mathrm{L}$ of percholoric acid (70\%) was reduced with gaseous hydrogen with $150 \mathrm{mg} 10 \%$ palladium on carbon under pressure during 25 minute. Percholoric acid was then neutralized with finely powdered $800 \mathrm{mg}$ of $\mathrm{CaCO}_{3}$. After the reaction it was filtered through glass wool and dried, the residue was got pure after chromatography using hexaneethyl acetate $(80: 20)$ mixture to yield $4 a$ as oil $(628$ mg, 92\%). Proton-NMR ( $\left.\mathrm{CDCl}_{3}\right) \delta: 7.94(\mathrm{Ar}-\mathrm{H}), 7.56$ (Ar-H), 7.16 (Ar-H), 7.04 (Ar-H), 5.83 (-O-CH-O-), $3.95\left(-\mathrm{O}-\mathrm{CH}_{2}-\mathrm{CH}_{2}-\right), 2.89$ (bs, $\left.1 \mathrm{H}, \mathrm{OH}\right), 2.30\left(\left(-\mathrm{O}-\mathrm{CH}_{2}-\right.\right.$ $\mathrm{CH}_{2}-$ ); C-13 NMR $\delta: 162.24,158.16,136.22,130.01$, 123.33, 116.66, 114.22, 99.73, 56.71, 36.21; MS $\left(\mathrm{C}_{9} \mathrm{H}_{8} \mathrm{O}_{4}\right)$ calcd. 180.042 found $\mathrm{MH}^{+}$181.1.

\section{4-Benzyloxy-1-butanal (2b)}

Butane-1,4-diol $(5.91 \mathrm{~g}, 66 \mathrm{mmol})$ and powdered potassium hydroxide (1.78 $\mathrm{g}, 32 \mathrm{mmol})$ was warmed at $120^{\circ} \mathrm{C}$ and after that the diol made free from water by vacuum distillation. Benzyl bromide $(4.44 \mathrm{~g}, 26 \mathrm{mmol}$ ) was then added slowly at $100^{\circ} \mathrm{C}$ from the dropping funnel. The reaction was continued to stirr for another $2 \mathrm{~h}$ at $100^{\circ} \mathrm{C}$. The product was stirred with $20 \mathrm{~mL}$ water after cooling it at room temperature. The crude product was extracted and dried with anhydrous $\mathrm{MgSO}_{4}$, concentrated and distilled to give $9.57 \mathrm{~g}(81 \%)$ of the monoprotected alcohol (4-benzyloxy-1-butanol).

4-Benzyloxy-1-butanol (3.89 g) was taken in a dropping funnel and added slowly to a mixtute of PCC $(7.28 \mathrm{~g})$ and dry $\mathrm{CH}_{3} \mathrm{COONa}(30 \mathrm{mg})$ dissolved in $50 \mathrm{~mL}$ of dichloromethane and stirred at room temperature for $2 \mathrm{~h}$ and the solution was rapidly passed through a small silica gel column. The filtrate part was concentrated and distilled quickly to give 4-benzyloxy-1-butanal as oil, $2.62 \mathrm{~g} \mathrm{(68 \% ).}$ Proton-NMR $\left(\mathrm{CDCl}_{3}\right) \delta: 9.78(-\mathrm{CHO}), 7.30(\mathrm{Ar}-\mathrm{H})$, 4.49 (s, $1 \mathrm{H}$, benzylic), $3.35\left(-\mathrm{O}-\mathrm{CH}_{2}\right), 2.55\left(-\mathrm{O}-\mathrm{CH}_{2}-\right.$ $\left.\mathrm{CH}_{2}\right), 1.95(\mathrm{C}-3 \mathrm{H}) . \mathrm{C}-13 \mathrm{NMR}\left(\mathrm{CDCl}_{3}\right) \delta: 202.0$, 128.35, 128.30.127.80 and 127.50 (aromatic), 72.90 (benzylic), 69.10, 41.00, 22.60. $\mathrm{MS}\left(\mathrm{C}_{10} \mathrm{H}_{12} \mathrm{O}_{2}\right)$ calcd. 164.084 found $\mathrm{MH}^{+}$165.1.

\section{2-(3'-Benzyloxypropyl)-4H-benz-1,3-dioxin-4-one (3b)}

Compound $\mathbf{2 b}$ was converted into $\mathbf{3 b}$ as described for the synthesis of $3 a(5.76 \mathrm{mmol}$ scale except benzyloxypropanaldehyde was used as aldehyde). After complete the reaction and purification the product benzodioxinone $\mathbf{3 b}$ was obtained, as liquid (1.13 g, 67\%). ${ }^{1} \mathrm{H}$ NMR $\delta: 7.97(\mathrm{Ar}-\mathrm{H}), 7.54(\mathrm{Ar}-\mathrm{H})$, 7.32 (Ar-H), 7.15(Ar-H), 7.01(Ar-H), 5.64 (-O-CH-O-), 4.52 (s, 2H, benzylic), $3.57\left(-\mathrm{O}-\mathrm{CH}_{2}\right), 2.15\left(\mathrm{O}-\mathrm{CH}_{2}-\right.$ $\left.\mathrm{CH}_{2}\right)$,), $1.92\left(\mathrm{O}-\mathrm{CH}_{2}-\mathrm{CH}_{2}\right)$,); $\mathrm{MS}\left(\mathrm{C}_{17} \mathrm{H}_{16} \mathrm{O}_{4}\right)$ calcd. 284.105 found $\mathrm{MH}^{+}$285.2.

\section{2-(3'-Hydroxypropyl)-4H-benz-1,3-dioxin-4-one (4b)}

Compound 2-(3'-benzyloxypropyl)-4Hbenz-1,3-dioxin-4-one $(2.0 \mathrm{~g})$ was taken in $20 \mathrm{~mL}$ 
ethyl acetate containing $10 \mu \mathrm{L}$ of percholoric acid (70\%) was reduced with gaseous hydrogen with 150 $\mathrm{mg} 10 \%$ palladium on carbon under pressure during 25 min same as the transformation from $3 \mathbf{a}$ to $\mathbf{4 a}$. Solvent was dried and concentrated using pump $(0.03 \mathrm{~mm} \mathrm{Hg})$ to yield $4 \mathrm{~b}(1.37 \mathrm{~g}, 94 \%)$ as a clear oil. The colourless oily substance was crystallized on storage at $-13^{\circ} \mathrm{C}$. m.p: $44^{\circ} \mathrm{C}$. Proton-NMR $\delta$ : 7.99 (Ar-H), 7.57 (Ar-H), 7.18 (Ar-H), 7.04 (Ar-H), 5.69 (-O-CH-O-), 3.65 (-O- $\left.\mathrm{CH}_{2}\right), 2.21(\mathrm{O}-\mathrm{CH}-\mathrm{O}-)$, 2.11 (-O-CH-O-). C-13 NMR ( $\left.\mathrm{CDCl}_{3}\right)$ 8: 162.76, $158.76,136.66,130.59,123.77,117.04$ and 114.79 (aromatic), 101.82, 62.33, 30.53, 26.33; MS $\left(\mathrm{C}_{10} \mathrm{H}_{10} \mathrm{O}_{4}\right)$ calcd. 194.058 found $\mathrm{MH}^{+}$195.2.

\section{2,4-Dihydroxyphenylbenzoate (6)}

Phenol (6.1 g,.065 mol), 2,4-dihydroxybenzoic acid $(11 \mathrm{~g})$ and trifluoroacetic anhydride (20 g) were mixed in ether $(50 \mathrm{~mL})$ and it was heated to refluxed at $65^{\circ} \mathrm{C}$ for 2 hours. $200 \mathrm{~mL}$ ether was added to the solution and ether layer was shaken well with saturated bicarbonate, brine solutions and concentrated. The crude product was treated with Norit in toluene and filtered. Hexane was added to it to get a white powder that was free of phenol. The compound was purified by crystalization from toluene-hexane mixture $(6: 4, v / v)$ provided white prisms (10.2 g, 67\%). m.p: $147-149^{\circ} \mathrm{C}$. Proton-NMR $\left(\mathrm{CDCl}_{3}\right) \delta: 10.73(\mathrm{OH}$ at C-2), $7.95(\mathrm{Ar}-\mathrm{H}), 7.43$ (Ar-H), 7.28 (Ar-H), $7.18($ Ar-H), $6.43(\mathrm{~m}, 2 \mathrm{H}), 6.09$ (bs, $1 \mathrm{H}, \mathrm{OH})$; $\mathrm{MS}\left(\mathrm{C}_{13} \mathrm{H}_{10} \mathrm{O}_{4}\right)$ calcd. 230.058 found $\mathrm{MH}^{+}$231.2.

\section{Phenyl-2-hydroxy-4-benyloxybenzoate (7)}

A solution of phenyl-2,4-dihydroxybenzoate $(1 \mathrm{~g})$, benzyl bromide $(744 \mathrm{mg}), \mathrm{K}_{2} \mathrm{CO}_{3}(684 \mathrm{mg})$ in $30 \mathrm{~mL}$ acetone was heated to refluxed for a day and night. Acetone was removed from the reaction mixture and the crude product was work-up with $\mathrm{CHCl}_{3}$, washed with $10 \%(\mathrm{v} / \mathrm{v}) \mathrm{HCl} / \mathrm{H}_{2} \mathrm{O}$ and then brine, passed through anhydrous $\mathrm{MgSO}_{4}$ and evaporated. The pure white solid was obtained by flash chromatography yielded phenyl-2-hydroxy-4benzyloxybenzoate $(0.64 \mathrm{~g}, 46 \%)$. m.p: $108-109^{\circ} \mathrm{C}$. Proton-NMR $\left(\mathrm{CDCl}_{3}\right) \delta: 10.69(\mathrm{OH}$ at $\mathrm{C}-2), 7.97$ (Ar-H), 7.29 (Ar-H), 6.59 (Ar-H), 5.10 (s, benzylic); MS $\left(\mathrm{C}_{20} \mathrm{H}_{16} \mathrm{O}_{4}\right)$ calcd. 320.105 found $\mathrm{MH}^{+} 321.3$.

2-nitrobenzyl alcohol (11.0 g, $0.072 \mathrm{~mol})$, chloroacetic acid $(1.68 \mathrm{~g})$ and $\mathrm{NaOH}(0.713 \mathrm{~g})$ in water $(4 \mathrm{~mL})$ was added slowly from dropping funnel with stirring over $20 \mathrm{~min}$ to acrolein $(25 \mathrm{~mL}, 20.98$ g). The solution was acidified with $\mathrm{CH}_{3} \mathrm{COOH}$ (7.5 $\mathrm{mL}, 0.13 \mathrm{~mol}$ ) and warmed at $40^{\circ} \mathrm{C}$ for 80 hours. The solution was chilled, shaken with water $(40 \times 3 \mathrm{~mL})$, and dried. The crude residue was then purified by chromatography furnished yellow oily product $(7 \mathrm{~g}$, $46.6 \%)$. Proton NMR $\left(\mathrm{CDCl}_{3}\right) \delta: 9.83(-\mathrm{CHO}), 8.04$ (Ar-H), 7.74 (Ar-H), 7.64 (Ar-H), $7.44($ Ar-H), 4.90 (s, 2H, benzylic), 3.93 (-O-CH-O-), $2.76\left(\mathrm{~m},-\mathrm{O}-\mathrm{CH}_{2}-\right.$ $\left.\mathrm{CH}_{2}\right)$. C-13 NMR $\left(\mathrm{CDCl}_{3}\right) \delta: 201.1,147.6,134.9$, $134.0,129.0,128.5,125.0,70.0,65.1,44.1$; MS $\left(\mathrm{C}_{10} \mathrm{H}_{11} \mathrm{NO}_{4}\right)$ calcd. 209.069 found $\mathrm{MH}^{+} 210.2$.

\section{2-[2'-(o-Nitrobenzyloxyethyl)-4H-1,3-benzdioxin- 4-one (9)}

A mixture of 3-(2'-nitrobenzyloxy) propionaldehyde ( $670 \mathrm{mg}, 3.2 \mathrm{mmol}$ ), 4-benzyloxy2-hydroxy phenyl benzoate (1.1 g) and DABCO (380 $\mathrm{mg}$ ) was warmed $40^{\circ} \mathrm{C}$ for $20 \mathrm{~min}$ and stirred it during $72 \mathrm{~h}$ at rt without solvent. Reaction mixture was then extracted with ethyl acetate. The organic layer was washed with $2 \% \mathrm{NaOH}$ solution ( $30 \times 3 \mathrm{~mL}$ ), then with water and concentrated. Pure product then obtained by flash chromatography to yield 9 (610 $\mathrm{mg}, 41 \%)$ as a viscuss oily substance. Proton NMR $\left(\mathrm{CDCl}_{3}\right) \delta$ : 8.03 (Ar-H), 7.89 (Ar-H), $7.73(\mathrm{Ar}-\mathrm{H}), 7.61(\mathrm{Ar}-\mathrm{H})$, $7.39(\mathrm{Ar}-\mathrm{H}), 6.77(\mathrm{Ar}-\mathrm{H}), 6.57(\mathrm{Ar}-\mathrm{H}), 5.80(\mathrm{Ar}-\mathrm{H})$, $5.11\left(\mathrm{~s}, \mathrm{CH}_{2} \mathrm{C}_{6} \mathrm{H}_{5}\right), 4.90\left(\mathrm{~s}, 2 \mathrm{H}, \mathrm{NO}_{2} \mathrm{C}_{6} \mathrm{H}_{4} \mathrm{CH}_{2}\right), 3.85$ (-O-CH-O-), 2.37 (q, 2H, - $\mathrm{O}-\mathrm{CH}_{2}-\mathrm{CH}_{2}$ ). C-13 NMR $\left(75 \mathrm{MHz}, \mathrm{CDCl}_{3}\right): \delta 165.2\left(\mathrm{C}-4^{\prime}\right), 161.9,160.2,147.3$, 135.6, 134.6, 133.6, 131.8, 128.7, 128.7, 128.6, 128.4, 128.1, 127.4, 127.4, 124.6, 111.9, 107.3 and 101.3 (aromatic) 99.3, 70.5 and 69.7 (benzylic), 65.2 and 34.1 (methylene); $\mathrm{MS}\left(\mathrm{C}_{24} \mathrm{H}_{21} \mathrm{NO}_{7}\right)$ calcd. 435.132 found $\mathrm{MH}^{+} 436.3$.

\section{2-(2'-Hydroxyethyl)-4H-7-benzyloxy-1,3-benzdioxin- 4-one (10)}

In a $200 \mathrm{~mL}$ rb was charged with $9(300 \mathrm{mg}$, $\mathrm{mmol}$ ), in $35 \mathrm{~mL}$ of dry THF. Reaction vessel was then purged with argon during half an hour and was stirred by keeping outside in ACE photochemical UV power supplies and murcurry vapour lamp for 7 hours. The solution was concentrated after the reaction yielded dark orange-red oil. The crude alcohol was purified by chromatograpy to yield white crystalline solid 160 mg $(77 \%)$, m.p: $110-111^{\circ} \mathrm{C}$. Proton- NMR $\left(\mathrm{CDCl}_{3}\right)$

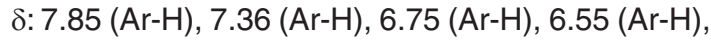
$5.78(\mathrm{Ar}-\mathrm{H}), 5.07(\mathrm{Ar}-\mathrm{H}), 3.92(-\mathrm{O}-\mathrm{CH}-\mathrm{O}-)$ ), 2.56 (bs, $1 \mathrm{H}, \mathrm{OH}$ ), $2.26\left(\mathrm{q}, 2 \mathrm{H},-\mathrm{O}-\mathrm{CH}_{2}-\mathrm{CH}_{2}\right) . \mathrm{C}-13 \mathrm{NMR}$ $\left(\mathrm{CDCl}_{3}\right) \delta: 165.6$ (C-4), 162.6, 160.6, 135.9, 132.2, 
129.2, 129.2, 128.8, 127.9, 127.9, 112.4, 107.5 and 101.8 (aromatic), 100.3, 70.9 (benzylic), 57.4 , 36.8; MS $\left(\mathrm{C}_{17} \mathrm{H}_{16} \mathrm{O}_{5}\right)$ calcd. 300.100 found $\mathrm{MH}^{+} 301.1$.

\section{2-(2'-Benzyloxyethyl)-3-methyl-4H-1,3-benzoxazin- 4-on (13a)}

Benzyloxy-propanaldehyde $(4.5 \mathrm{~g}, 0.027$ $\mathrm{mol}$ ) and $5 \mathrm{~mL}$ ortho-phosphoric acid was mixed $\mathrm{N}$-methyl salicylamide ( $4.14 \mathrm{~g}, 0.027 \mathrm{~mol})$ in THF. The reaction vessel was refluxed for $14 \mathrm{~h}$ (TLC control). Then THF was removed from the system and work up with ethyl acetate and concentrated. The pure product was obtained by flash chromatographed to give $13 \mathrm{a}$ as an oily substance $(2.4 \mathrm{~g}, 31.6 \%)$. Proton NMR $\left(\mathrm{CDCl}_{3}\right) \delta: 7.93(\mathrm{Ar}-\mathrm{H}), 7.33(\mathrm{Ar}-\mathrm{H})$, $7.02(\operatorname{Ar}-\mathrm{H}), 6.86(\mathrm{Ar}-\mathrm{H}), 5.49(\mathrm{Ar}-\mathrm{H}), 4.49$ (s, 2H, benzylic), 3.54 (-O-CH-O-), 3.03 (s, N-CH $\left.{ }_{3}\right), 2.08$ (m, O- $\mathrm{CH}_{2}-\mathrm{CH}_{2}$ ); $\mathrm{MS}$ (C17H17NO3) calcd. 283.121 found $\mathrm{MH}^{+}$284.3.

\section{2-(2'-Hydroxyethyl)-3-methyl-4H-1,3-benzoxazin- 4-one (14a)}

Substance 2-(2'-benzyloxyethyl)-4H-1,3benzoxazin-4-one 13a was converted to $14 a$ as reported for the synthesis of $13 a(1.5 \mathrm{mmol}$ scale). The pure compound was obtained by flash chromatography to yield $14 \mathrm{a}$ as an oily substance ( $300 \mathrm{mg}, 96 \%)$, Proton $\operatorname{NMR}\left(\mathrm{CDCl}_{3}\right) \delta: 7.93(\mathrm{Ar}-\mathrm{H}), 7.42(\mathrm{Ar}-\mathrm{H}), 7.08(\mathrm{Ar}-\mathrm{H})$, 6.9 (Ar-H), 5.53 (Ar-H), 3.8 (m, -O-CH-O-), 3.10 (s, 3H, $\left.\mathrm{NCH}_{3}\right)$, $2.1\left(\mathrm{~m},-\mathrm{O}-\mathrm{CH}_{2}-\mathrm{CH}_{2}\right)$; C-NMR NMR $\left(\mathrm{CDCl}_{3}\right)$ : $\delta$ 162.2, 155.7, 134.72, 127.5, 122.5, 118.2, 117.2, 87.0, 57.1, 34.5, $30.5\left(\mathrm{NCH}_{3}\right)$; MS $\left(\mathrm{C}_{10} \mathrm{H}_{11} \mathrm{NO}_{3}\right)$ calcd. 193.074 found $\mathrm{MH}^{+} 194.2$.

\section{2-(3'-Benzyloxypropyl)-3-methyl-4H-benz-1,3- dioxin-4-one (13b)}

Product $13 b$ was prepared from $12 b$ as described for the synthesis of 13a $(13.2 \mathrm{mmol}$ scale except benzyloxy-propanaldehyde was used as aldehyde). The pure compound was obtained by flash chromatography to efford the benzodioxinone $13 b$, as an oily substance $(1.4 \mathrm{~g}, 37 \%) . R_{\mathrm{f}}=0.45$ (hexane/ EtOAc, 6.5 : 3.5). Proton NMR $\left(\mathrm{CDCl}_{3}\right) \delta: 7.90(\mathrm{Ar}-\mathrm{H})$, 7.31 (Ar-H), 6.97 (Ar-H), 7.15 (Ar-H), $6.85($ Ar-H), 5.26 (Ar-H), 4.47 (s, 2H, benzylic), 3.50 (m, -O-CH-O-), 3.05 $\left(\mathrm{s}, 3 \mathrm{H}, \mathrm{NCH}_{3}\right), 1.85\left(\mathrm{~m},-\mathrm{O}-\mathrm{CH}_{2}-\mathrm{CH}_{2}-\right), \mathrm{MS}\left(\mathrm{C}_{18} \mathrm{H}_{19} \mathrm{NO}_{3}\right)$ calcd. 297.137 found $\mathrm{MH}^{+}$298.3.

\section{2-(2'-Hydroxypropyl)-3-methyl-4H-1,3-benzoxazin- 4-one (14b) \\ 2-(2'-benzyloxypropyl)-4H-1,3-benzoxazin-} 4-one $\mathbf{1 3 b}$, was converted to $14 \mathrm{~b}$ as mentioned for the synthesis of $13 \mathrm{a}(1.5 \mathrm{mmol}$ scale). The pure compound was obtained by flash column chromatography on silica using $\mathrm{CHCl}_{3} / \mathrm{MeOH}$ (97:3 to $95: 5, \mathrm{v} / \mathrm{v}$ ) as eluent to afford $\mathbf{1 4} \mathrm{b}$ as a colorless oil (310 mg, 97\% ): $\mathrm{R}_{\mathrm{f}} 0.41\left(9: 1 \mathrm{CHCl}_{3}: \mathrm{MeOH}\right)$. Proton $\operatorname{NMR}\left(\mathrm{CDCl}_{3}\right): \delta 7.9(\mathrm{Ar}-\mathrm{H}), 7.41(\mathrm{Ar}-\mathrm{H}), 7.06(\mathrm{Ar}-\mathrm{H})$, $6.90(\mathrm{Ar}-\mathrm{H}), 5.29$ (Ar-H), 3.64 (m, -O-CH-O-), 3.07 $\left(\mathrm{s}, 3 \mathrm{H}, \mathrm{NCH}_{3}\right), 1.86\left(\mathrm{~m},-\mathrm{O}-\mathrm{CH}_{2}-\mathrm{CH}_{2}-\right)$; C-NMR NMR $\left(\mathrm{CDCl}_{3}\right): \delta 161.4,155.1,134.1,127.7,122.2,118.0$, 116.7, 89.3, 61.6, 31.0 (NCH3), 28.6, 27.6; MS $\left(\mathrm{C}_{11} \mathrm{H}_{13} \mathrm{NO}_{3}\right)$ calcd. 207.090 found $\mathrm{MH}^{+}$208.3.

\section{CONCLUSION}

In this work different types of salicylate and salicylamide alcohols were synthesized for the preparation of phosphorodiamidates and ifosfamide prodrugs.

\section{ACKNOWLEDGEMENT}

The author wish to thank Former Professor D. Farquar for his necessary guidance in the work and Dr.W. Bormmann, Former Professor, M.D. Anderson Cancer Center for his support and discussion in the work.

\section{Conflicts of Interest}

None

\section{REFERENCES}

1. Rautio, J.; Kumpulainen, H.; Heimbach, T.; Oliyai, R.; Oh, D.; Järvinen, T. Nat Rev Drug Discov., 2008, 7(3), 255-70.

2. Wu, K. M. Pharmaceuticals (Basel)., 2009, 2(3), 77-81.

3. Buxton, I. L. O. Pharmacokinetics and Pharmacodynamics: The Dynamics of Drug Absorption, Distribution, Action, and Elimination. In: Brunton, L. L.; Lazo, J. S.; Parker, K. L.
Goodman \& Gilman's the Pharmacological Basis of Therapeutics. 11th ed. New York: McGraw-Hill Medical Pub. Division., 2005, 1-11.

4. Goldstein, A.; Aronow, L.; Kalman, S. M. Principles of Drug Action: the basis of pharmacology. 2nd ed. NJ, USA: John Wiley \& Sons; Hoboken., 1974.

5. Zawilska, J. B.; Wojcieszak, J.; Olejniczak, A. B. Pharmacol Rep., 2013, 65, 1-14. 
6. Stella, V. J. J Pharm Sci., 2010, 99, 4755-65.

7. Huttunen, K. M.; Raunio, H.; Rautio, J. Pharmacol Rev., 2011, 63, 750-71.

8. Rautio, J.; Meanwell, N. A.; Di, L. Nat Rev Drug Discov., 2018, 17(8), 559-587.

9. Rautio, J.; Kärkkäinen, J.; Sloan, K. B. Eur J Pharm Sci., 2017, 109, 146-161.

10. Najjar, A.; Najjar, A.; Karaman, R. Molecules., 2019, 16, 1-5.

11. Struck, R. F. Isophosphoramide mustard analogs and use thereof, PCT Int. Appl., 2000, 34, CODEN: PIXXD2 WO. 2000071134 A1.

12. Sladek, N. E. Pharmacol. Ther., 1988, 37, 301-355.

13. Sladek, N.E. Oxazaphosphorines, Metabolism and Action of Anticancer Drugs.; Powis, G., Prough, R. A., Eds.; Taylor and Francis: London., 1987, 48-90.

14. Friedman, O.M.; Myles, A.; Colvin, M Cyclophos -phamide and Related phosphoramide Mustards, Advances in Cancer Chemotherapy, Rosowsky, A.; Marcel Dekker: Newyork., 1979, 143-204.
15. Hill, D.L. A Review of Cyclophosphamide; Charles C. Thomas: Springfield, IL., 1975.

16. Zon, G. Prog. Med. Chem., 1982, 19, 205-246.

17. Stec, W. J. Organophosphate Chem., 1982, 13, 145-174.

18. Wang, Y. and Farquhar, D. J. Med. Chem., 1991, 34, 197-203.

19. Struck, R. F.; Kirk, M. C.; Witt, M. H.; Laster, W. R. Jr. Biomed. Mass Spectrom., 1975, 2, 46.

20. Struck, R. F.; Dykes, D. J.; Corbett, T. H.; Suling, W. J.; Trader, M.W. B. J. Cancer., 1983, 47, 15.

21. Friedman, O. M.; Wodinsky, I.; Myles, A. Cancer Treat. Rep., 1976, 60, 337.

22. Hipkings, J. H.; Struck, R. F.; Gurtoo, H. L. Cancer Res., 1981, 41, 3571.

23. El-Din, N. S. Acta Pharm., 2000, 50, 239-248.

24. Feldman, K. S.; Lawlor, M. D.; Sahasrabudhe, K. J. Org. Chem., 2000, 65, 8011-8019.

25. Zon, G.; Ludeman, S. M.; Brandt, J. A.; Boyd, V. L.; Ozkan, G.; Egan, W.; Shao, K. L. J. Med. Chem., 1984, 27, 466-485.

26. Brown, F. J. J. Med. Chem., 1989, 32, 807-826. 